\title{
Minimum Alveolar Concentration 50 Percent
}

National Cancer Institute

\section{Source}

National Cancer Institute. Minimum Alveolar Concentration 50 Percent. NCI Thesaurus.

Code C139130.

A unit of potency for inhalational gases, defined as the concentration of gas in the lung required to immobilize $50 \%$ of individuals in response to a stimulus, such as pain. 